\title{
The influence of sex and age on the deposition of L-xyloascorbic acid in tissues of guinea-pigs
}

\author{
By R. E. HUGHES AND P. R. JONES \\ University of Wales Institute of Science and Technology, Cardiff
}

(Received 6 February 1970-Accepted 27 Fuly 1970)

\begin{abstract}
I. Young male and female guinea-pigs of similar age and male guinea-pigs of various ages were given daily oral supplements of vitamin $\mathbf{C}$ (L-xyloascorbic acid) (AA) on a body-weight basis for periods of $10-15 \mathrm{~d}$ and the resulting concentration of $\mathrm{AA}$ in several organs was determined.

2. There was no difference between the sexes in the concentrations of AA in the adrenal glands and spleen. The concentration of AA in the spleen, adrenal glands and eye lens was significantly lower in older animals, and in brain it was significantly higher than the corresponding values for the young guinea-pigs.

3. The tissue deposition after oral administration of AA for rod was compared with that resulting from intramuscular injection of the same quantity of $A A$ over ro $d$ in males aged $60 \mathrm{~d}$, males aged $500 \mathrm{~d}$ and females aged $500 \mathrm{~d}$. In the $60-\mathrm{d}$-old guinea-pigs intramuscular injection raised the concentration of $A A$ in the spleen and adrenal glands $35 \%$ and $50 \%$ respectively above that resulting from oral dosing. In the older guinea-pigs (500 d) the corresponding values were $108 \%$ and $127 \%$ respectively. It is concluded that reduced gastrointestinal absorption is, at least in part, responsible for the low AA concentrations in certain organs from older guinea-pigs. In the 500-d-old guinea-pigs there was no significant difference between the AA levels in the spleen, adrenals and brain of the two sexes, but AA level in the lens of females was significantly lower than that in males, irrespective of the mode of administration of the AA.
\end{abstract}

A number of reports have indicated that in man the vitamin C (L-xyloascorbic acid) (AA) content of both the plasma and the leucocytes is related to the sex of the subject (Kirk \& Chieffi, I958; Kataria, Rao \& Curtis, 1965; Brook \& Grimshaw, r968). Both plasma and leucocyte AA are known to parallel the dietary intake of the vitamin (Burch, I96I) and it is possible that the age and sex relationships are merely reflections of different dietary patterns. On the other hand, plasma and leucocyte AA values are frequently taken as an index to the tissue levels of $\mathrm{AA}$ and are widely quoted as a measure of vitamin $\mathrm{C}$ status. If indeed there are changes in the tissue AA that parallel those observed in the blood elements, then sex and age could well be critical factors when the intake of AA is marginal and should be regarded as such in any recommendations for optimal intakes of the vitamin. Such considerations could be of especial significance in the light of recent indications that already many people in the United Kingdom do not obtain the amount of vitamin $\mathrm{C}$ recommended to provide a good margin of safety (Allen, Brook \& Broadbent, ı968).

The experiments described in this report were designed primarily to determine whether, in guinea-pigs, age and sex are determinants for tissue concentrations of AA. The spleen and adrenal glands were, in the majority of the experiments, used as representative tissues in this respect despite the known occurrence of stress-induced fluctuations in their AA content in certain circumstances. The spleen has been shown 
to be a useful index to vitamin $\mathrm{C}$ status over a wide range of dietary intakes (Ginter, Bobek \& Gerbelova, I965; Hughes \& Jones, unpublished work.)

In some of the experiments the AA content of the eye lens and that of the brain were measured, as there have been recent suggestions that AA is specifically involved in the metabolism of these two organs (e.g. Heath, I962; Pauling, I968).

\section{EXPERIMENTAL}

\section{Animals and diet}

Albino guinea-pigs were used. Male guinea-pigs reach sexual maturity at 2-3 months and females somewhat earlier (Lane-Petter \& Porter, r963). In the experiments described in this report guinea-pigs up to $75 \mathrm{~d}$ old are designated 'young'; those within the range 76-499 d 'mature' and those over $500 \mathrm{~d}$ 'old' (guinea-pigs will in fact survive for a number of years, but in practice it is difficult to use those over I 8 months for nutritional studies as they react adversely to changes in diet and housing).

The conditions of housing, diet and dosing of the guinea-pigs were as previously described (Hughes \& Hurley, r969). In Expts I, 2, 4, 5 and 6 the animals were housed in groups of four; in Expt 3 they were housed individually.

\section{Ascorbic acid determination}

Tissue AA was determined by the 2:6-dichlorophenolindophenol method previously described (Bessey, 1938; Hughes, 1956).

\section{Plan of experiments}

In all experiments the guinea-pigs first received the unsupplemented scorbutogenic diet for Io $\mathrm{d}$ to deplete the tissues of AA.

Expts I and 2. Groups of male and female guinea-pigs were given a single oral dose of AA daily for $15 \mathrm{~d}$. In Expt $\mathrm{I}$, young guinea-pigs ( $35 \mathrm{~d}$ old) were used and they received $0.2 \mathrm{mg} \mathrm{AA} / 100 \mathrm{~g}$ body-weight; in Expt 2, mature guinea-pigs (roo d old) were used and they received $0.5 \mathrm{mg} \mathrm{AA} / 100 \mathrm{~g}$ body-weight. The AA concentrations in the spleen and adrenal glands were determined.

Expts 3, 4 and 5. In Expt 3, male guinea-pigs from different age-groups received a single daily oral dose of $0.5 \mathrm{mg} \mathrm{AA} / 100 \mathrm{~g}$ body-weight for Io $\mathrm{d}$ and the concentrations of $\mathrm{AA}$ in the spleen and adrenal glands were determined.

In Expts 4 and 5, higher doses of AA were administered; the AA concentrations in the adrenal glands, brain and lens were determined in young and old guinea-pigs that had received a daily dose of $\mathrm{x} \cdot 8 \mathrm{mg}$ (Expt 4) or $100 \mathrm{mg}$ (Expt 5) per 100 $\mathrm{g}$ bodyweight for a period of ro d.

Expt 6. The tissue concentrations of AA resulting from two modes of administration (oral and intramuscular) were measured in two groups of male guinea-pigs aged 60 and $500 \mathrm{~d}$ respectively and in female guinea-pigs aged $500 \mathrm{~d}$. The dose of AA administered was $0.5 \mathrm{mg} / \mathrm{roO} \mathrm{g}$ body-weight daily for $\mathrm{ro} \mathrm{d}$. 


\section{RESULTS}

The results are summarized in Tables 1,2 and 3 .

Neither in the adrenal glands nor in the spleen was there any significant difference between the AA concentrations in the two sexes (Table I). This was true of young animals ( $35 \mathrm{~d}$ old) that had received $0.25 \mathrm{mg} \mathrm{AA} / 100 \mathrm{~g}$ body-weight (Expt I; Table I) and of mature animals ( $100 \mathrm{~d}$ old) that had received $0.5 \mathrm{mg} \mathrm{AA} / \mathrm{ro0} \mathrm{g}$ body-weight (Expt 2; Table I).

Table I. Expts I and 2. Ascorbic acid $(A A)$ concentrations in tissues of male and female guinea-pigs

(Mean values with their standard errors. The figures in parentheses are the numbers of guinea-pigs in each group)

\begin{tabular}{|c|c|c|c|c|c|c|c|}
\hline \multirow[b]{2}{*}{ Sex } & \multirow[b]{2}{*}{$\begin{array}{l}\text { Body-wt } \\
\text { (g) }\end{array}$} & \multicolumn{3}{|c|}{ Adrenal glands } & \multicolumn{3}{|c|}{ Spleen } \\
\hline & & $\begin{array}{l}\mathrm{Wt} \\
(\mathrm{mg})\end{array}$ & $\begin{array}{l}\text { Wt as \% } \\
\text { body-wt }\end{array}$ & $\underset{(\mathrm{mg} / \mathrm{I}(00 \mathrm{~g})}{\mathrm{AA}}$ & $\begin{array}{l}\mathrm{Wt} \\
(\mathrm{mg})\end{array}$ & $\begin{array}{l}\text { Wt as \% } \\
\text { body-wt }\end{array}$ & $\underset{(\mathrm{mg} / \mathrm{I} / 0 \mathrm{~g})}{\mathrm{AA}}$ \\
\hline \multicolumn{8}{|c|}{35 -d-old animals; dosed for $15 \mathrm{~d}$ with $0.2 \mathrm{mg} \mathrm{AA} / 100 \mathrm{~g}$ body-wt } \\
\hline$\sigma^{t}(6)$ & $325 \pm 22 \cdot 3$ & $193 \pm 5 \cdot 9$ & $\begin{array}{l}0.061 \pm \\
0.003\end{array}$ & $13 \cdot 8 \pm \mathrm{x} \cdot 25$ & $439 \pm 31 \cdot 0$ & $\begin{array}{l}0.136 \pm \\
0.014\end{array}$ & $4.3 \pm 0.54$ \\
\hline q $(6)$ & $320 \pm 11 \cdot 5$ & $170 \pm 4 \cdot 5$ & $\begin{array}{l}0.054 \pm \\
0.004\end{array}$ & $13.3 \pm 0.68$ & $402 \pm 10 \cdot 2$ & $\begin{array}{l}0.127 \pm \\
0.013\end{array}$ & $4^{\circ} \pm \pm 0.27$ \\
\hline \multicolumn{8}{|c|}{ I00-d-old animals; dosed for $15 \mathrm{~d}$ with $0.5 \mathrm{mg} \mathrm{AA} / \mathrm{r} 00 \mathrm{~g}$ body-wt } \\
\hline$\sigma(\mathrm{r})$ & $690 \pm 14 \cdot 0$ & $283 \pm 13 \cdot 2$ & $\begin{array}{l}0.041 \pm \\
0.002\end{array}$ & $27 \cdot 2 \pm x \cdot 43$ & $873 \pm 21 \cdot 4$ & $\begin{array}{l}0.126 \pm \\
0.005\end{array}$ & I I.0 \pm 0.55 \\
\hline$q(12)$ & $55^{6} \pm 8 \cdot 9$ & $294 \pm 10.9$ & $\begin{array}{l}0.053 \pm \\
0.002\end{array}$ & $29 \cdot 3 \pm I \cdot 2 I$ & $767 \pm 36 \cdot 2$ & $\begin{array}{l}0.138 \pm \\
0.006\end{array}$ & $10.86 \pm 0.55$ \\
\hline
\end{tabular}

Table 2. Expts 3 (groups I-4), 4 (groups 5,6 ) and 5 (groups 7,8 ). Tissue concentration of ascorbic acid $(A A)$ in male guinea-pigs of selected age-groups given daily oral doses of $A A$

(Mean values with their standard errors; the ages given are those at the commencement of the experiment and the figures in parentheses are the numbers of animals in each group)

\begin{tabular}{|c|c|c|c|c|c|c|c|}
\hline \multirow[b]{2}{*}{ Group } & \multirow[b]{2}{*}{$\begin{array}{l}\text { Age } \\
\text { (d) }\end{array}$} & \multirow{2}{*}{$\begin{array}{c}\text { AA dose } \\
\text { (mg/Ioo g } \\
\text { body-wt } \\
\text { d) }\end{array}$} & \multirow{2}{*}{$\begin{array}{c}\text { Final } \\
\text { body-wt } \\
\text { (g) }\end{array}$} & \multicolumn{4}{|c|}{ AA concentration $(\mathrm{mg} / \mathrm{r} 00 \mathrm{~g})$} \\
\hline & & & & $\begin{array}{l}\text { Adrenal } \\
\text { glands* }\end{array}$ & Spleen $†$ & Brain & Lens§ \\
\hline I (8) & 28 & 0.50 & $352 \pm 16$ & $37 \cdot 5 \pm 3 \cdot 0$ & II.O \pm 0.43 & - & - \\
\hline $2(6)$ & 73 & 0.50 & $498 \pm 22$ & $26 \cdot 0 \pm I \cdot 3$ & $I I \cdot 3 \pm 0.60$ & - & 一 \\
\hline $3(6)$ & 130 & 0.50 & $742 \pm 22$ & $24 \cdot 6 \pm I \cdot I$ & $12.0 \pm 0.61$ & - & - \\
\hline $4(6)$ & 470 & 0.50 & $887 \pm 53$ & $18 \cdot 4 \pm 2 \cdot 5$ & $4 \cdot 12 \pm I \cdot 60$ & - & - \\
\hline $5(5)$ & 70 & 1.80 & $537 \pm 31$ & $50 \cdot 6 \pm 3 \cdot 2$ & T & $9.5 \pm 0.6$ & $9 \cdot 0 \pm 0.4$ \\
\hline $6(4)$ & 495 & $1 \cdot 80$ & $1001 \pm 45$ & $44 \cdot 6 \pm 4 \cdot 0$ & 一 & $14.8 \pm 0.3$ & $7 \cdot 8 \pm 0 \cdot 4$ \\
\hline $7(5)$ & 70 & 100 & $543 \pm 33$ & $67 \cdot 5 \pm 5 \cdot 0$ & 一 & $10 \cdot 2 \pm 1 \cdot 0$ & $10.7 \pm 0.6$ \\
\hline $8(5)$ & 495 & 100 & $1023 \pm 19$ & $62 \cdot 4 \pm 6 \cdot 0$ & - & $15.0 \pm 0.5$ & $7 \cdot 3 \pm 0.4$ \\
\hline
\end{tabular}

* Difference between means of groups $I$ and 2,1 and 3,2 and 4 , and 3 and 4 significant at $5 \%$ level and of groups $\mathrm{I}$ and 4 at $\mathrm{I} \%$ level.

$\dagger$ Difference between means of groups I and 4,2 and 4 , and 3 and 4 significant at I \% level.

$\$$ Difference between means of groups 5 and 6 significant at $0.1 \%$ level and of groups 7 and 8 at I \% level.

$\S$ Difference between means of groups 7 and 8 significant at I \% level. 
With age, a distinct relationship emerged. With increase in age, there was a decrease in the concentration of $\mathrm{AA}$ in the adrenal glands. The difference between the young and mature animals in adrenal AA concentration was significant at the $5 \%$ level and that between the young and old animals at the I \% level (Expt 3, Table 2). There was no significant difference between young and mature guinea-pigs in spleen AA concentration, but a marked difference existed between the mature and old ones. In old guinea-pigs, spleen and adrenal gland concentrations of AA were approximately half those found in young guinea-pigs (Table 2).

A similar, though less marked, pattern existed in young and old guinea-pigs given larger doses of AA (Table 2). As did the AA in the adrenal glands, the lens AA too showed age-correlated changes. In the brain, however, the relationship was reversed; with both the $1.8 \mathrm{mg}$ and the $100 \mathrm{mg}$ AA doses, the older brains had higher AA concentrations than the young ones $(P<\mathrm{x} \%)$.

Table 3. Expt 6. Tissue concentrations of ascorbic acid $(A A)$ in guinea-pigs given $0.5 \mathrm{mg} A A / 100 \mathrm{~g}$ body-weight daily for $8 d$

(Mean values with their standard errors. The figures in parentheses are the numbers of animals in each group)

\begin{tabular}{|c|c|c|c|c|c|c|c|}
\hline \multirow[b]{2}{*}{$\begin{array}{c}\text { Mode of } \\
\text { administration } \\
\text { of AA }\end{array}$} & \multirow[b]{2}{*}{$\begin{array}{l}\text { Age } \\
\text { (d) }\end{array}$} & \multirow[b]{2}{*}{ Sex } & \multicolumn{5}{|c|}{ Ascorbic acid concentration ( $\mathrm{mg} / \mathrm{l} 00 \mathrm{~g}$ tissue) } \\
\hline & & & $\begin{array}{c}\text { Body-wt } \\
\text { (g) }\end{array}$ & $\begin{array}{l}\text { Adrenal } \\
\text { glands }\end{array}$ & Spleen & Brain & Lens* \\
\hline Orally & 60 & $\partial(6)$ & $381 \pm 12$ & $20 \cdot 6 \pm \mathrm{I} \cdot 86$ & $7.77 \pm 0.92$ & 一 & - \\
\hline Intramuscl & 60 & ठૈ (7) & $384 \pm I 3$ & $30 \cdot 9 \pm 2 \cdot 6 r$ & $10.50 \pm 2 \cdot 12$ & - & 一 \\
\hline Orally & 485 & $\delta(6)$ & $837 \pm 55$ & $18 \cdot 6 \pm 2 \cdot 5^{\circ}$ & $4 \cdot I I \pm I \cdot 4 I$ & $6 \cdot 00 \pm 0 \cdot 45$ & $4.40 \pm 0.26$ \\
\hline Intramuscularly & 485 & $\sigma(5)$ & $796 \pm 41$ & $38 \cdot 2 \pm 9 \cdot 54$ & $9 \cdot 35 \pm 2 \cdot 35$ & $7 \cdot 82 \pm 0.94$ & $5.25 \pm 0.4 I$ \\
\hline Orally & 485 & $q(5)$ & $873 \pm 47$ & $19.01 \pm 1.59$ & $5 \cdot 75 \pm 1 \cdot 56$ & $5 \cdot 59 \pm 1 \cdot \times 7$ & $3 \cdot 13 \pm 0.20$ \\
\hline Intramuscularly & 485 & 우 (5) & $921 \pm 52$ & $37 \cdot 24 \pm 3 \cdot 26$ & I $1 \cdot 28 \pm I \cdot 48$ & $7.96 \pm 0.85$ & $3.86 \pm 0.24$ \\
\hline
\end{tabular}

* Difference between lens AA concentration of male and female 'dosed' guinea-pigs significant at $r \%$ level and between those of male and female 'injected' guinea-pigs at $5 \%$ level.

Expt 6 was designed to determine to what extent these age-linked decrements in the AA content of the adrenals, spleen and lens were related to a possible agedependent impairment of absorption, similar to that known to occur in man for certain nutrients (Bender, I968). In young animals, the concentrations of AA in the spleen and adrenals after intramuscular injection were $35 \%$ and $50 \%$ respectively above the values produced by oral dosing. In the older guinea-pigs the corresponding values were $108 \%$ and $127 \%$ respectively. Intramuscular injection raised the spleen concentration of AA of the older guinea-pigs to within $90 \%$ of that of young animals, whereas the adrenal AA of the old injected animals in fact exceeded that of the injected young ones.

In the older animals the difference in tissue concentrations resulting from the two modes of administration was much less in the brain and eye lens than in the spleen and adrenals. There was a significant difference between the eye lens AA concentrations of the two sexes irrespective of the mode of administration (Table 3 ). 


\section{DISCUSSION}

No difference due to sex was found between the AA concentrations in the spleen and adrenal glands of guinea-pigs dosed orally with controlled amounts of AA. This was true for two levels of dose $(0.2 \mathrm{mg}$ and $0.5 \mathrm{mg} / \mathrm{roog}$ body-weight $)$ and in both young and sexually mature animals. These findings are of interest because of recent reports of a sex difference in the blood concentrations of AA in man. In three groups within the age range 20-60 years, Brook \& Grimshaw (1968) found that males had lower plasma AA concentrations than females. Dodds (1969) confirmed this and explained her finding, that the difference was less marked in very young and in very old subjects, by suggesting that a difference between the sexes in AA metabolism was responsible.

The metabolism of AA in guinea-pigs is known to differ in certain respects from its metabolism in man, and one should therefore have reservations about the importance of the above results to human subjects. Nevertheless, our results do not provide any support for the belief that the AA metabolism of tissues in general is influenced by the sex of the animal (Dodds, 1969). Two points are of interest in this respect. First, it is possible that the sex effect in man derives primarily from, and is detectable only in, the blood. This would occur if, for example, there were sex-correlated changes in the activity of the AA-stabilizing system of the erythrocyte (Hughes, 1964) or in the permeability of the erythrocyte membrane to AA (Hughes \& Maton, I968). Secondly, in the absence of control of dietary intakes, it is impossible to discount in man the possibility that the different blood AA values are primarily a reflection of a sex-based difference in dietary patterns.

The only organ where a sex difference in AA concentration was apparent was the eye lens, the males having significantly higher concentrations of AA than the females and this irrespective of whether the AA was administered orally or intramuscularly (Expt 6, Table 3). Of possible relevance is the recent finding that the permeability of the lens membranes towards AA is fundamentally different from the behaviour of a number of other biological membranes examined (Hughes \& Hurley, 1969).

The experiments designed to examine the relationship between age and tissue concentrations (Expts 3,4 and 5) indicated a reduction in AA concentration in the adrenal glands, spleen and eye lens with increase in age (Table 2). Different tissues appeared to behave differently in this respect. Thus, a significant fall in the concentration in adrenal glands was apparent at a fairly early age, whereas in the spleen the concentration remained fairly constant until the guinea-pigs reached a post-maturity stage. As one would expect, these age-correlated changes were more marked at a suboptimal intake of AA $(0.5 \mathrm{mg} / \mathrm{ro0} \mathrm{g}$ body-weight), although in the eye lens there was a significant negative correlation with age, even at an intake of $100 \mathrm{mg} / \mathrm{ro0} \mathrm{g}$ body-weight.

Assuming that the spleen, adrenal glands and lens are in this respect representative of the guinea-pig tissues as a whole, it would appear that in male guinea-pigs increase in age is associated with lower tissue concentrations of AA. This, if applied to man, is in keeping with the age-correlated decreases in blood AA already reported by a 
number of workers (see above). A possible explanation of a relationship of this type is that in the ageing animal the efficiency of the gastro-intestinal absorption processes is reduced. It is well established that the ageing process is frequently characterized by reduced absorption of certain nutrients (Bender, 1968), and Expt 6 was designed to determine to what extent impaired absorption could be responsible for the results obtained in Expts 3, 4 and 5. If it is assumed that there is no difference in the rate of diffusion of AA from the site of injection, the results would appear to indicate reduced gastro-intestinal absorption of AA in older animals.

Increasing the oral intake of AA from $\mathrm{r} \cdot 8 \mathrm{mg}$ to $100 \mathrm{mg} / \mathrm{r} 00 \mathrm{~g}$ body-weight produced the expected increase in adrenal gland concentration of AA (Table 2; cf. Penney \& Zilva, 1946). No marked increase, however, occurred in the AA content of the lens and brain with increase in dose administered-neither in young nor old animals. A possible explanation is that these tissues have a more efficient abstracting or retaining mechanism, or both, for AA, so that optimal working levels are attainable in circumstances that produce only suboptimal (or submaximal) levels in other tissues. There is evidence that AA has a metabolic role in the eye lens (Heath, I962), and more recently the suggestion has been made that it has biochemical involvements in the brain also (Pauling, I968).

Organs in which AA has metabolic involvements could well have developed mechanisms for its more efficient abstraction and retention.

Finally, it will be observed that the behaviour of the brain was anomalous in one further respect, namely that the concentrations of $\mathrm{AA}$ were greater in the older animals than in the young ones. With a dose of $\mathrm{I} .8 \mathrm{mg} / \mathrm{r} 00 \mathrm{~g}$ body-weight the older guinea-pigs had a brain AA concentration $55.8 \%$ above that of the young ones $(P<0.1 \%)$; and with a dose of $100 \mathrm{mg} / \mathrm{I} 00 \mathrm{~g}$ body-weight the increase was $47 \%$ $(P<1 \%)$. This is the opposite of the results obtained for the other tissues examined and points to the existence of a special age-linked relationship between brain tissue and AA. One cannot discount, in this respect, the distinction between brain growth and somatic growth. Both in man (Cheek, Migeon \& Mellits, 1968) and in guinea-pigs (P. R. Jones, unpublished observations) the brain achieves its mature size much earlier than other organs. This means that in guinea-pigs receiving AA on a body-weight basis (as in the experiments described in this report) the amount of the AA dose per unit weight of brain tissue is greater in mature animals than in young ones. On the other hand, it is possible that the greater concentrations of $\mathrm{AA}$ in the ageing brain are merely an adventitious reflection of a change in the metabolism of the organ. If, as present evidence appears to suggest, there is a direct biochemical involvement of AA in the metabolism of the brain and the retention of AA by the brain reflects this, then it is possible to interpret these results in terms of a greater dependence of the ageing brain upon AA.

This work was supported by a generous grant from Beecham Products (UK). 


\section{REFERENCES}

Allen, R. J. L., Brook, M. \& Broadbent, S. R. (1968). Br. F. Nutr. 22, 555.

Bender, A. D. (1968). Y. Am. Geriat. Soc. 16, r331.

Bessey, O. A. (1938). F. biol. Chem. 126, 771.

Brook, M. \& Grimshaw, J. J. (1968). Am. F. clin. Nutr. 21, 1254.

Burch, H. B. (r96r). Ann. N.Y. Acad. Sci. 92, 268.

Cheek, D. B., Migeon, C. J. \& Mellits, E. D. (1968). In Human Growth p. 54r [D. B. Cheek, editor]. Philadelphia: Lea \& Febiger.

Dodds, M. ( ( 969). F. Am. diet. Ass. 54, 32.

Ginter, E., Bobek, P. \& Gerbelova, M. (1965). Nutritio. Dieta. 7, 103.

Heath, H. (I962). Expl Eye Res. x, 362.

Hughes, R. E. (1956). Biochem. F. 64, 203.

Hughes, R. E. (1964). Nature, Lond. 203, 1068.

Hughes, R. E. \& Hurley, R. J. (1969). Br. F. Nutr. 23, 2 II.

Hughes, R. E. \& Maton, G. C. (1968). Br. F. Haemat. 14, 247.

Kataria, M. S., Rao, D. B. \& Curtis, R. C. (1965). Geront. clin. 7, 189.

Kirk, J. E. \& Chieffi, M. (1958). F. Geront. 8, 30 r.

Lane-Petter, W, \& Porter, G. (1963). In Animals for Research: Principles of Breeding and Management p. 287 [W. Lane-Petter, editor]. London and New York: Academic Press.

Pauling, L. (x968). Science, N.Y. x60, 265.

Penney, J. R. \& Zilva, S. S. (1946). Biochem. F. 40, 695. 